\title{
重心移動課題における足関節筋の同時収縮に及ぼす加齢の影響
}

\author{
相 馬 優 樹 ${ }^{11}$ \\ 衣笠 隆 ${ }^{1)}$ \\ 漆 畑 俊 哉 ${ }^{1,2)}$ 三好 寛 和 ${ }^{1)}$
}

\section{AGING EFFECTS ON CO-CONTRACTION OF ANKLE MUSCLES DURING VOLUNTARY SWAY TASK}

\author{
YUKI SOMA, TAKASHI KINUGASA, \\ TOSHIYA URUSHIHATA and HiROKAZU MiYOSHI
}

\begin{abstract}
The aim of this study was to compare co-contraction of ankle muscles between older and young adults performing a voluntary sway task, and identify any relationships between $\mathrm{co}^{-}$contraction, balance ability and muscular strength. The task involved displacement of the center of mass backwards and forwards continually during upright stance under three amplitude conditions, large, small and preferred, with sway speeds of slow, medium and fast. The participants comprised 17 older (64.1 \pm 2.9 years) and 14 young $(21.3 \pm 3.3$ years) women. Electromyographic recordings were obtained from the tibialis anterior and the medial gastrocnemius muscles during task performance to calculate the $\mathrm{co}^{-}$contraction index $(\mathrm{CCI})$ and evaluate the relative level of co-contraction of antagonist muscle. Additional measurements were obtained from balance tests including body sway tests, functional reach, gait tests, and the EquiTest (Neurocom), and also muscular strength of plantar flexion and dorsiflexion. The CCI was highest under large sway amplitude, but did not differ among sway speeds. The CCI was higher in the older group (23\%) than in the young group (15\%). Multiple regression analysis revealed that the CCI correlated with body sway in the EquiTest and functional reach, and dorsiflexion strength. Therefore, this study suggested that co-contraction of ankle muscles increased with aging and related to not only static and dynamic balance abilities, but also ankle dorsiflexor strength.
\end{abstract}

(Jpn. J. Phys. Fitness Sports Med. 2010, 59:143 156)

key word : older adults, falls, $c^{-}$contraction index, balance ability, muscle strength

$$
\text { I . 緒言 }
$$

加齢によるバランス能力の低下は転倒・骨折を生 じ , 要介護になるリスクを高める ${ }^{1,2)}$.このために , バランス能力の低下した高齢者を早期に識別するこ とは要介護や寝たきりを予防する上で重要である . バランス能力は樣々な課題を用いて評価される が，立位姿勢を保持するために足関節筋である腓腹 筋やヒラメ筋, 前脛骨筋の筋活動が不可欠である ${ }^{3)}$. 特に，立位姿勢のバランス課題において高齢者や転 倒恐怖を持つ者は, 足底屈筋である腓腹筋（あるい はヒラメ筋) と足背屈筋である前脛骨筋を同時に活
動させる同時収縮を起こしやすいことが明らかとな っている ${ }^{4 \sim 6)}$.

Manchester et al. は可動式の起立台上で立位姿 勢を維持している対象者に台の前後移動による外乱 を加える課題を 3 回試行した時の大腿四頭筋，ハム ストリングス, 前脛骨筋, 腓腹筋の筋活動を観察し た。弚の結果，全試行で同時収縮を起こした若年者 は18\%だったが，高齢者では44\%であった ${ }^{4)}$. また， Laughton et al. は安静立位姿勢保持課題を 10 試行 行った時の上腿と下腿の筋活動を観察したところ， 高齢者は若年者に比べて同時収縮を起こす試行数が 1.5〜5 倍になることを報告した ${ }^{5)}$. Benjuya et al.
1)筑波大学大学院人間総合科学研究科 干 305-8574 茨城県つくば市天王台 1-1-1

2) 筑波技術大学保健科学部

干 305-8521 茨城県つくば市春日4-12-7
Graduate School of Comprehensive Human Sciences, University of Tsukuba. Faculty of Health Sciences, Tsukuba University of Technology. 
によると, 安静立位姿勢における足関節筋の筋活動 を観察したところ, 高齢者で前脛骨筋の筋活動量が 高まり，足関節筋の同時収縮が強まることを明らか にしだ）.

このように，同時収縮に関する先行研究で用いら れた課題は台移動などの外乱や安静立位である . 高 齢者の転倒はつまずきや滑りのような外乱を含む動 的な立位姿勢保持の崩れによって生じ, 安静立位で は少ない7)。また, 従来の外乱による研究では, 同 時収縮が足圧中心の移動距離や速度に依存する可能 性があるが，これらの関連を考慮していない，一方， 高齢者の転倒はバランス能力や筋力の低下と関連す る報告があるので ${ }^{8,9)}$ ，加齡に伴う同時収縮の増加 はバランス能力あるいは筋力の低下と関連する可能 性がある.しかしながら, 現在のところ, 同時収縮 がバランス能力や下肢筋力と関連することを明らか にした研究は見当たらない．

乥こで, 本研究では地域在住の中高齢者と若年者 を対象に, 動的な立位姿勢保持課題を用いて足関節 筋にみられる同時収縮に及ぼす加齢の影響を明らか にする．このために，足関節を軸に体を前後に傾け る前後重心移動課題を用い, 課題中の足圧中心の移 動距離と速度を変化させて同時収縮に及ぼす影響を 検証する .さらに，足関節筋の同時収縮とバランス 能力，ならびに筋力との関連を明らかにする．本研 究の仮説は, 中高齢者において前後重心移動課題時 に足関節の同時収縮が強まり, 同時収縮の強さは足 圧中心の移動距離と速度に依存する.さらに同時収 縮の強さはバランス能力や筋力に関連することであ る.

$$
\text { II. 方法 }
$$

\section{A. 対象者}

対象者は, 募集の呼びかけに応じた, 地域在住の 60 歳以上の中高齢者 17 名と若年者 14 名である. 前者 を中高齢群，後者を若年群とした．対象者はいずれ も女性であり, 神経筋系, 聴覚, 視覚の障害はみら れなかった .なお, 本研究は筑波大学研究倫理委員 会の承認 (2008年度623番) の下で行われ, 対象者 全員から同意書を得た .

\section{B．実験装置}

後述する前後重心移動課題を行う際, 利き脚の前
脛骨筋 (TA)，腓腹筋内側 (GM) から表面筋電図 を導出した . 安静立位においてはヒラメ筋への依存 が大きいとされるが ${ }^{3)}$, 前後重心移動課題において ヒラメ筋よりも腓腹筋に活発な筋活動がみられたた め, 本研究では足底屈筋として GM を選択した。電 極には直径 $5 \mathrm{~mm}$ の双極銀電極を用い，筋腹付近に 電極間距離 $20 \mathrm{~mm}$ で装着した．電極間の電気抵抗は $10 \mathrm{k} \Omega$ 以下に処理した . 筋電図の信号は生体電気用 アンプ (三栄社製1253A) によって増幅し，フィル ターを $5.3 \mathrm{~Hz} \sim 1000 \mathrm{~Hz}$ に設定した . 弚の後 $\mathrm{AD}$ 変換 (NATIONAL INSTRUMENT社, LabVIEW 7 , サン プリング周波数 $2000 \mathrm{~Hz})$ し , パーソナルコンピュー タに記録した。

前後重心移動課題を実施するために，4 点式重心 動摇計測システム (共和電業製，K06-6407，測定 周波数 $100 \mathrm{~Hz}$ ) を用い, 足圧中心移動軌跡 (COP) を測定した ここのシステムは，センサインタフェー ス (共和電業製， $\mathrm{PCD}$-300A) と重心計 (共和電業 製，PLH-K150-KYW) で構成されている．測定さ れた COP はパーソナルコンピュータに記録した .

\section{C. 実験手順}

すべての対象者は形態測定，前後重心移動課題， バランステスト，筋力テストを行った .

1 . 形態測定

形態は身長, 体重, 体脂肪率, つま先から踵まで の足長を測定した .

\section{2 . 前後重心移動課題}

対象者は重心計の上で立位姿勢を保持し，両足を 接するロンベルグ肢位をとり，股関節を屈曲せず， 足底を重心計に接し，足関節を軸に体を前後に傾け る前後重心移動課題を行った。課題は体を前後に傾 ける速度を 3 段階, 前後方向の足圧中心移動距離( 以 下，振幅）を 3 段階，合計 9 条件を実施した。速度 は電子メトロノームを用い，(1遅い(Slow；0.25Hz)， (2)中間 (Middle; $0.375 \mathrm{~Hz}$ ), (3)速い (Fast; 0.5Hz) とした . 振幅は，(1)できるだけ大きく (Large)，(2) 小さく (Small ; Largeの半分程度の振幅), (3)任意 (Preferred) とした .課題の順序は速度が遅い，中間， 速いであった . 光れ光れの速度において振幅は，で きるだけ大きく，小さく，任意の順に 1 試行ずつ行 つた . 対象者は，指示された振幅と速度ができるま で練習を行った．対象者が前後重心移動課題を開始 
し, 往復運動を 2,3 回行った後, 足圧中心を最後 方に移動させた時点で測定を開始した．1 試行の測 定時間は30秒であつた．1つの速度 ( 3 試行) の測 定終了後に, 対象者は椅子に座って休敗をとった． 3 . バランステスト

バランステストとして, 重心動摇テスト ${ }^{10)}$, ファ ンクショナルリーチ ${ }^{11}$ ), 開眼・閉眼片足立ち（最 大 60 秒) , $11 \mathrm{~m}$ 歩行 (全力歩行時の速度, 歩幅, 歩 行率) $^{12)}$ ，EquiTest (NeuroCom社製) を用いた感 覚統合機能テス卜 (Sensory Organization Test: 以 下SOT) および運動調節機能テスト (Motor Control Test : 以下MCT) ${ }^{13)}$ を行った .なお, 重心動摇テス 卜では開・閉眼時の重心動摇軌跡長 (LNG) と面積 (AREA)，11m歩行では全力歩行時の速度 (Speed), 歩幅 (Step length), 歩行率 (Cadence) を測定した.

SOTは, 起立台が安定した開眼 (C1) と閉眼 (C2), 前景が動く (C3), 起立台が不安定で開眼 (C4) と 閉眼 (C5), 前景が動く (C6), 計 6 条件で行った。 対象者は，いずれの条件においても20秒間可動式の 台上で静止立位を維持した . 試行中の姿勢動摇に基 づいた得点を算出し，動摇が小さいほど高得点を与 えた.SOTの 6 条件乥れ光れの得点の他に, 総合得 点 (SOT) も算出した.MCTでは, 水平移動する 台の外乱が開始してから対象者の姿勢反応が起こる までの潜時を測定した .

4 . 筋力テスト

足背屈力および足底屈力は, 等速性筋力測定装置
(Cybex6000) を用いて，60\%/secおよび $180^{\circ} / \mathrm{sec} の$ 角速度における体重あたりのピークトルク $(\mathrm{Nm} / \mathrm{kg})$ を測定した。

5 . データ解析

1 ) $\mathrm{Co}^{-}$contraction index (CCI) の算出

前後重心移動課題中における足関節筋の同時収縮 を評価するために，Falconer \& Winterの方法を用 いて以下のようにC $\mathrm{Co}^{-}$contraction index (CCI) を算 出した ${ }^{14)}$. はじめに, コンピュータに保存された 筋電図の波形をLabVIEW 7を用いて全波整流し， ローパスフィルター (カットオフ周波数 $2 \mathrm{~Hz}, 3$ 次 元のバタワース) によって包絡線化した . 以上の処 理を行った波形から，安静時のベースラインの平均 振幅の值を減じ，最大随意収縮時の最大振幅によっ て標準化した ${ }^{15)}$.さらに，これらの処理を経た波 形を画像として保存した後に，TAとGMの合成し た筋電図画像をFigure 1 に示したように作成した . この時，灰色，白，黑の面積は弚れ光れ TA，GM， 同時収縮を表しており，式1を用いてCCI（\%)を 算出した。

$\mathrm{CCI}(\%)=\frac{2 * \text { 黑の面積 }}{\text { 灰色の面積 }+ \text { 白の面積 }+2 * \text { 黑の面積 }} \cdots$ 式 1

なお, 最大随意収縮時の筋電図を得るために, 対 象者は, 膝関節屈曲 $90^{\circ}$, 足関節底屈 $0^{\circ}$ の座位姿勢 をとり，徒手抵抗に対する等尺性収縮による足関節 の背屈, 底屈を 1 回ずつ, 3 秒間最大努力で行った。

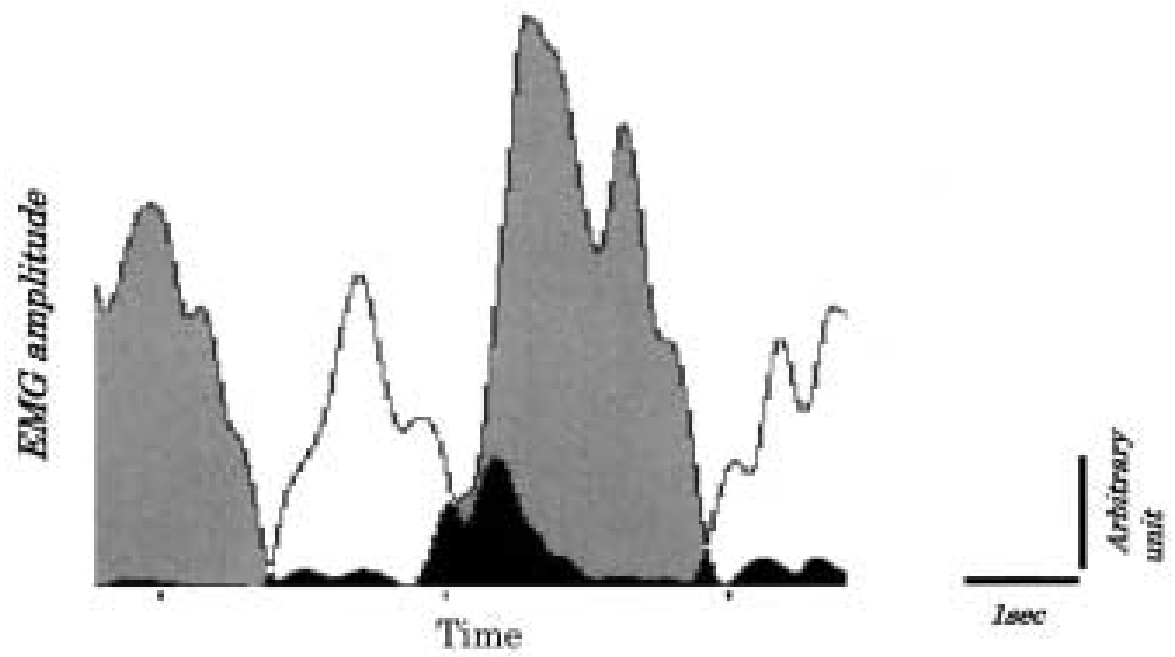

Figure 1. Gray, white, and black areas show filtered and rectified EMG of the tibialis anterior, gastrocnemius, and $\mathrm{co}^{-}$contraction, respectively. Therefore, CCI was calculated as follows; $\mathrm{CCI}=(2 \mathrm{black}) /($ gray + white $+2 \mathrm{black})$. 
Table 1. Physical characteristics of the old and young groups

\begin{tabular}{lcccccc}
\hline & unit & \multicolumn{2}{c}{ Old $(\mathrm{n}=17)$} & \multicolumn{2}{c}{ Young $(\mathrm{n}=14)$} & \multirow{2}{*}{ P-value } \\
\cline { 3 - 6 } & & mean & S.D. & mean & S.D. & \\
\hline Age & year & 64.1 & 2.9 & 21.3 & 3.3 & $<0.001$ \\
Height & $\mathrm{cm}$ & 152.5 & 4.9 & 157.1 & 6.1 & $<0.05$ \\
Weight & $\mathrm{kg}$ & 53.3 & 6.3 & 51.7 & 7.1 & n.s. \\
\% Body Fat & $\%$ & 28.2 & 5.6 & 25.2 & 3.7 & n.s. \\
Foot Length & $\mathrm{cm}$ & 22.4 & 1.0 & 22.9 & 1.0 & n.s. \\
\hline
\end{tabular}

2 ) $\% \mathrm{AP}-\max$ の算出

対象者は踵から足指まで重心計に接し，できるだけ 体を前後に傾けた .この時の足圧中移動距離を測定し， 最大前後足圧中心移動距離とした．前後重心移動課題 時における足圧中心移動距離より, 最大前後足圧中心 移動距離に対する割合を算出し，\%AP-max とした .

6 . 形態による補正

ファンクショナルリーチ, 最大前後足圧中心移動 距離, 歩行速度, 歩幅, 歩行率は形態に依存するた め，以下の式を用いて補正した .

ファンクショナルリーチ＝実測したファンクショ ナルリーチ $/$ 補正身長

足長\% (Foot length $\%)=$ 最大前後足圧中心移動距 離/足長

但し, 補正身長 $=$ 身長 $/$ 全対象者の身長の平均值 とした。

歩行速度, 歩幅, 歩行率は衣笠たち ${ }^{16)}$ の方法に よって補正した。

7 . 統計処理

前後重心移動課題の速度 (Slow, Middle, Fast), 振幅 (Large ,Preferred,Small) ,さらに年齢群間 (中 高齢群，若年群) の相違を明らかにするために， \%AP-max , CCI を用いて分散分析を行った . また， 筋活動が筋群 (TA, GM) だけではなく, 前後重心 移動課題の速度，振幅，年齢群間の相違を明らかに するために分散分析を行った .いずれも事後検定と して Bonferroni 法を用いた . 形態測定 , バランス テスト，筋力テストの成績が中高齢群と若年群間で 相違することを明らかにするために対応のない $\mathrm{t}$ 検 定を用いた . CCI とバランステスト，筋力テスト， 年齢の関連を明らかにするためにピアソンの相関分 析と逐次重回帰分析を行った．有意水準はすべて 5
\%未満とした.なお，統計処理にはSPSS 16.0を用 いた。

$$
\text { III. 結果 }
$$

\section{A. 対象者の特徵}

中高齢群と若年群の年齢と形態的特徵を Table 1 に示した . 形態に関する測定項目において, 身長が 中高齢群で有意に低かった .

B. 前後重心移動課題における足圧中心移動軌跡 前後重心移動課題における振幅, 速度光れ光れの \%AP-max の平均値と標準偏差を Table 2 に示した . 振幅は Large（中高齢群： $88.5 \%$, 若年群 : $92.8 \%$ ) で最も大きく，Preferred (中高齢群 : $79.0 \%$, 若年 群 : 79.4\%), Small (中高齢群 : $51.4 \%$, 若年群 : 49.9\%) の順であった $(\mathrm{p}<0.001)$. しかしながら， 速度に関して Slow, Middle, Fastの間で\%AP-max の相違はみられなかった .

課題中の\% $\%$ AP- $\max$ は, 中高齢群と若年群で相違が みられなかった．すなわち，いずれの課題でも中高 齢群の足圧中心移動距離は, 若年群と同樣であった .

以上のように, 前後重心移動課題において, 中高 齢群，若年群ともに\%AP-max は指示したとおりに Large, Preferred, Smallに分けて行い, 速度の速 い場合でも\%AP-maxの減少はみられなかった .中 高齢群の\%AP-max は若年群と同等であった .

\section{C. 前後重心移動課題における筋活動}

中高齢群と若年群における TA と GM の筋活動を 振幅で評価し, 光の平均值と標準偏差を光れ光れ Figure 2, Figure 3 に示した . 前後重心移動課題時 の振幅が大きくなると, TA，GMの筋活動はとも 
Table 2. \%AP-max during the voluntary sway task in the old and young groups

\begin{tabular}{|c|c|c|c|c|c|c|}
\hline \multirow{2}{*}{ Speed } & \multirow{2}{*}{ Amplitude } & \multirow{2}{*}{ Unit } & \multicolumn{2}{|c|}{ Old $(n=17)$} & \multicolumn{2}{|c|}{ Young $(n=14)$} \\
\hline & & & mean & S.D. & mean & S.D. \\
\hline \multirow{3}{*}{$\begin{array}{c}\text { Slow } \\
(0.25 \mathrm{~Hz})\end{array}$} & Large & $\%$ & 88.4 & 5.7 & 92.3 & 5.4 \\
\hline & Preferred & $\%$ & 77.5 & 10.4 & 78.2 & 5.8 \\
\hline & Small & $\%$ & 51.6 & 7.6 & 49.0 & 6.6 \\
\hline \multirow{3}{*}{$\begin{array}{c}\text { Middle } \\
(0.375 \mathrm{~Hz})\end{array}$} & Large & $\%$ & 88.4 & 5.7 & 92.8 & 3.9 \\
\hline & Preferred & $\%$ & 78.8 & 11.2 & 80.6 & 4.3 \\
\hline & Small & $\%$ & 51.0 & 7.6 & 48.4 & 6.2 \\
\hline \multirow{3}{*}{$\begin{array}{c}\text { Fast } \\
(0.5 \mathrm{~Hz})\end{array}$} & Large & $\%$ & 88.7 & 4.4 & 93.2 & 3.9 \\
\hline & Preferred & $\%$ & 80.8 & 10.4 & 79.5 & 5.1 \\
\hline & Small & $\%$ & 51.6 & 7.4 & 52.3 & 7.4 \\
\hline
\end{tabular}

に増大し $(\mathrm{p}<0.01)$, 特に, TAの筋活動の増大は GMよりも大きかった $(p<0.01)$. 前後重心移動課 題時の速度が増大すると, TA, GMの筋活動はと もに増大したが $(\mathrm{p}<0.05)$, TAの筋活動の増大は GMと同等であった .

\section{D. 前後重心移動課題における CCI}

Figure 4 は各課題の中高齢群と若年群の筋活動 の一例である .すべての課題における平均 CCI は中 高齢群で $23 \%$, 若年群で15\%であり, 中高齢群で高 かった $(\mathrm{p}<0.05)$. Figure 4 に示したように，中 高齢群は若年群と比較して, 黑の面積でみられるよ うに強い同時収縮を起こしていた．若年群と中高齢 群の TA の筋活動は足圧中心が前方から後方に移動 する時にみられたが，さらに中高齢群のTAの筋活 動は足圧中心が後方から前方に移動する時にもみら れた .

中高齢群と若年群における CCI の平均値と標準偏 差を Table 3 に示した . CCIは振幅の Large (25\%)

で最も高く, Preferred (17\%) とSmall (15\%) と比
べて有意であった $(\mathrm{p}<0.001)$. Preferred $(17 \%)$ とSmall (15\%) の間に有意差はみられなかった . Figure 5は, 中高齢群のLarge, Preferred, Small における筋電図の一例である .

一方, 遅い, 中間, 速いと速度を変化させても， CCI に変化がみられなかった .

E ．バランステストと筋カテストの結果 バランステスト (Table 4-1) と筋カテスト (Table 4-2) において，23項目中12項目で年齢群間 に有意差か認められた .すなわち，バランス能力， 筋力ともに中高齢群で低下した .ただし, 足背屈力 に有意差はみられなかった .

F . CCIとバランステスト, 筋カテストの関係 CCIの代表値として , 振幅の中間である Preferred を用い, CCIは速度に依存しないことから，3段階 の速度の平均值を算出し, aveCCI とした . aveCCIと バランステスト，筋力テストの関係を明らかにする ために，ピアソンの相関係数を算出した .この時， 


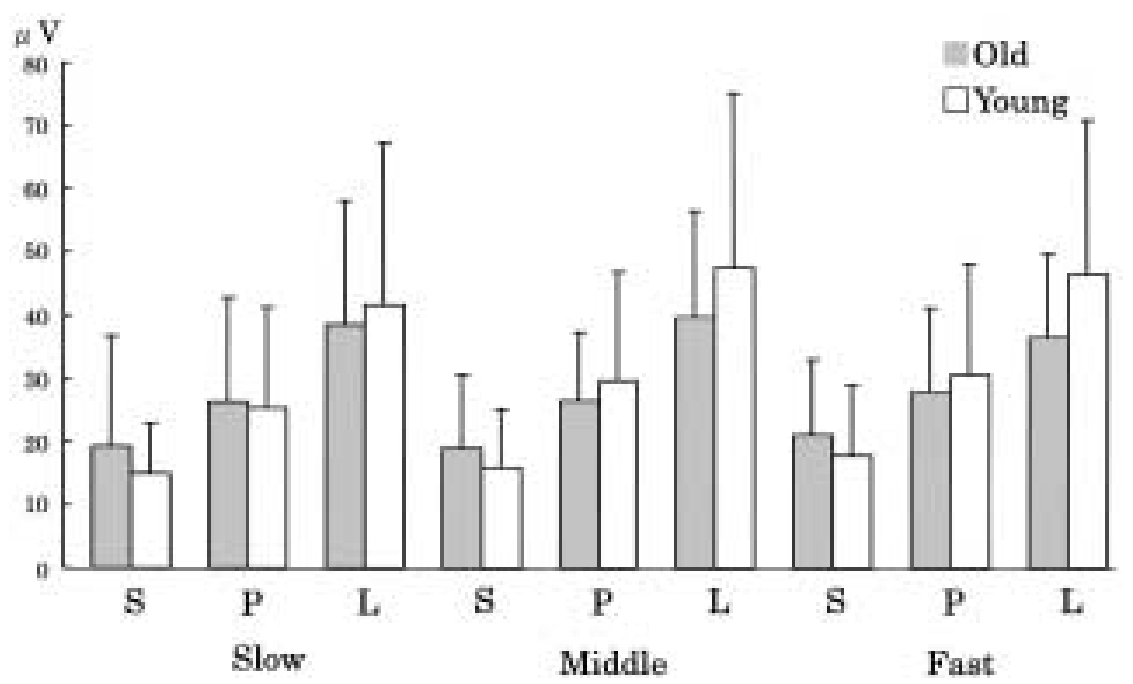

L=Large, P=Preferred, Sismall

Figure 2. EMG activity of the tibialis anterior for the old and young groups in the voluntary sway tasks.

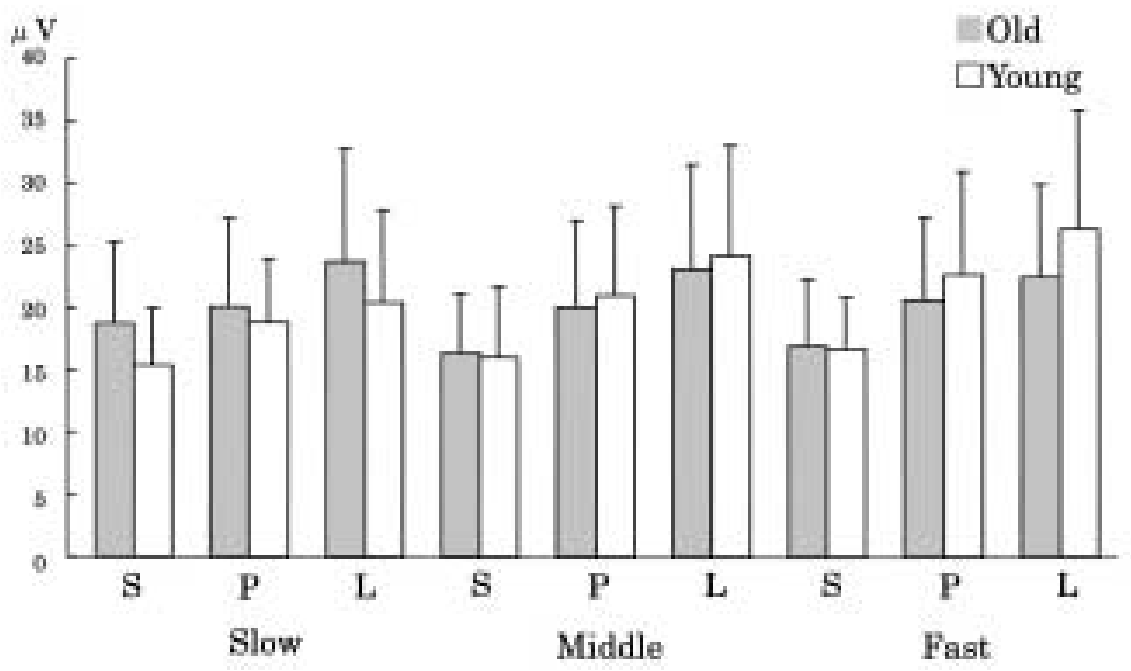

$\mathrm{L}=$ Large, $\mathrm{P}=$ Preferred, $\mathrm{S}=\mathrm{Small}$

Figure 3. EMG activity of the gastrocnemius for the old and young groups in the voluntary sway tasks.

分析には中高齢群と若年群すべての測定値を用いた . aveCCI と有意な相関のみられたバランステスト は , SOTのC2 ( $\mathrm{r}=0.451, \mathrm{p}<0.05)$ とファンクシ ヨナルリーチ $(\mathrm{r}=-0.459, \mathrm{p}<0.01)$ であった .また , aveCCI と有意な相関のみられた筋力テストは足背 屈ピークトルク $60^{\circ} / \mathrm{sec} \quad(\mathrm{r}=-0.474, \mathrm{p}<0.01)$ ，な らびに $180^{\circ} / \mathrm{sec}(\mathrm{r}=-0.498, \mathrm{p}<0.01)$ であった .

逐次重回帰分析では aveCCI を従属変数とし, モ デルIにおいてはバランステストのみ, モデルIIで
はバランステストと筋力テスト，モデルயIIではバラ ンステスト，筋力テスト，年齢を説明変数に投入し た .弚の結果，モデル I ではC2 $(\beta=0.432, \mathrm{p}<0.01)$, ファンクショナルリーチ $(\beta=-0.441, \mathrm{p}<0.01)$ の 2 つハバランステストを抽出した .モデルIIでは， $180^{\circ} / \mathrm{sec}$ の足背屈ピークトルク $(\beta=-0.398, \mathrm{p}<$ $0.01), \mathrm{C} 2(\beta=0.406, \mathrm{p}<0.01)$, ファンクショナ ルリーチ $(\beta=-0.365, \mathrm{p}<0.05)$ を抽出した . モ デル Iからモデル II にかけて決定係数は 0.14 増加し 


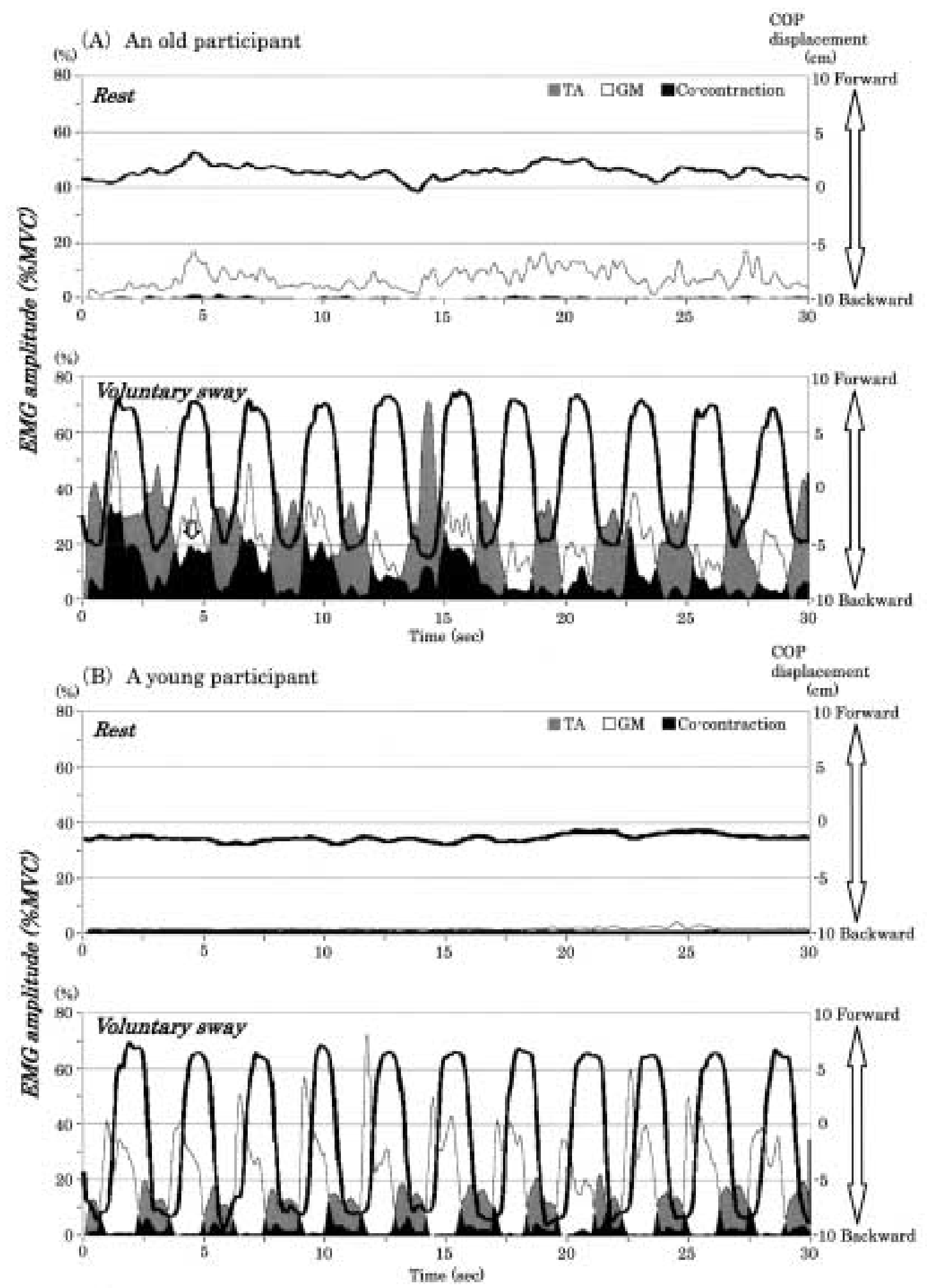

Figure 4. Examples of EMG and COP trajectory for an old (A) and a young (B) participants during the upright stance as rest and the voluntary sway task with the amplitude of Large at the middle speed of $0.375 \mathrm{~Hz}$. Gray, white, and black areas show EMG of the tibialis anterior, gastrocnemius, and $\mathrm{co}^{-}$contraction, respectively. 
Table 3. CCI for the old and young groups in the voluntary sway task

\begin{tabular}{|c|c|c|c|c|c|c|}
\hline \multirow{2}{*}{ Speed } & \multirow{2}{*}{ Amplitude } & \multirow{2}{*}{ unit } & \multicolumn{2}{|c|}{ Old $(n=17)$} & \multicolumn{2}{|c|}{ Young $(n=14)$} \\
\hline & & & mean & S.D. & mean & S.D. \\
\hline \multirow{3}{*}{$\begin{array}{c}\text { Slow } \\
(0.25 \mathrm{~Hz})\end{array}$} & Large & $\%$ & 33.2 & 15.6 & 22.9 & 11.2 \\
\hline & Preferred & $\%$ & 23.9 & 15.5 & 13.7 & 9.5 \\
\hline & Small & $\%$ & 21.1 & 16.4 & 8.6 & 5.3 \\
\hline \multirow{3}{*}{$\begin{array}{c}\text { Middle } \\
(0.375 \mathrm{~Hz})\end{array}$} & Large & $\%$ & 26.6 & 12.6 & 23.3 & 9.5 \\
\hline & Preferred & $\%$ & 19.0 & 10.8 & 13.7 & 9.1 \\
\hline & Small & $\%$ & 20.2 & 10.0 & 10.0 & 7.2 \\
\hline \multirow{3}{*}{$\begin{array}{c}\text { Fast } \\
(0.5 \mathrm{~Hz})\end{array}$} & Large & $\%$ & 24.0 & 10.1 & 20.0 & 8.4 \\
\hline & Preferred & $\%$ & 19.5 & 11.2 & 12.5 & 6.7 \\
\hline & Small & $\%$ & 23.1 & 14.4 & 9.5 & 7.1 \\
\hline
\end{tabular}

た．モデルIIIでは年齢を説明変数に投入したが，モ デルПで抽出された変数の有意性は変わらなかった (Table 5) .

$$
\text { N. 考察 }
$$

A. 同時収縮と前後重心移動課題中の振幅·速度 の関連

本研究において, 足関節を軸に体を前後に傾ける 前後重心移動課題の振幅を増大させたところ, 中高 齢者と若年者はともに前脛骨筋と腓腹筋の筋活動を 高め, 同時収縮は強くなった .この結果は, 台移動 時の同時収縮を観察したHorak et al. ${ }^{17)}$ と Maki \& Ostrovski ${ }^{18)}$ の報告と一致した . 特に, 課題中の振 幅が大きくなるとともに前脛骨筋の筋活動が高まっ たことにより，同時収縮が強まった可能性がある．

一方 本研究の前後重心移動課題で速度を増すと， 中高齢者と若年者はともに前脛骨筋と腓腹筋の筋活 動量は増大させたが, 同時収縮は変わらなかった . また, 課題中に速度を速めても, 前脛骨筋と腓腹筋 の筋活動の相違はみられなかった .
以上のように，中高齢者と若年者にみられた同時 収縮は前後重心移動課題の振幅に依存するが，速度 に依存しなかった .一方，中高齢者は若年者に比べ て，特定の条件で同時収縮か増大するとは言えなか った .

\section{B. 同時収縮の加齢変化}

本研究の前後重心移動課題中における前脛骨筋と 腓腹筋の筋活動を観察したところ，中高齢者は若年 者に比べて強い同時収縮を示した，特に，中高齢群 の前脛骨筋の筋活動が顕著であったために同時収縮 を強めたと推察される.この結果は, 高齢者の安静 立位姿勢において前脛骨筋の筋活動の高まりが，足 関節筋の同時収縮を強めたことを報告した Benjuya et al. ${ }^{6)}$ を支持した .

中高齢者において前後重心移動課題中の同時収縮 が強まった要因の第 1 に筋力の低下が挙げられる. 一般に中高齢者において筋力の低下がみられ，本研 究においても中高齢者は若年者に比べて足底屈筋力 が低下した (Table 4-2) . 足関節まわりの筋力は， 

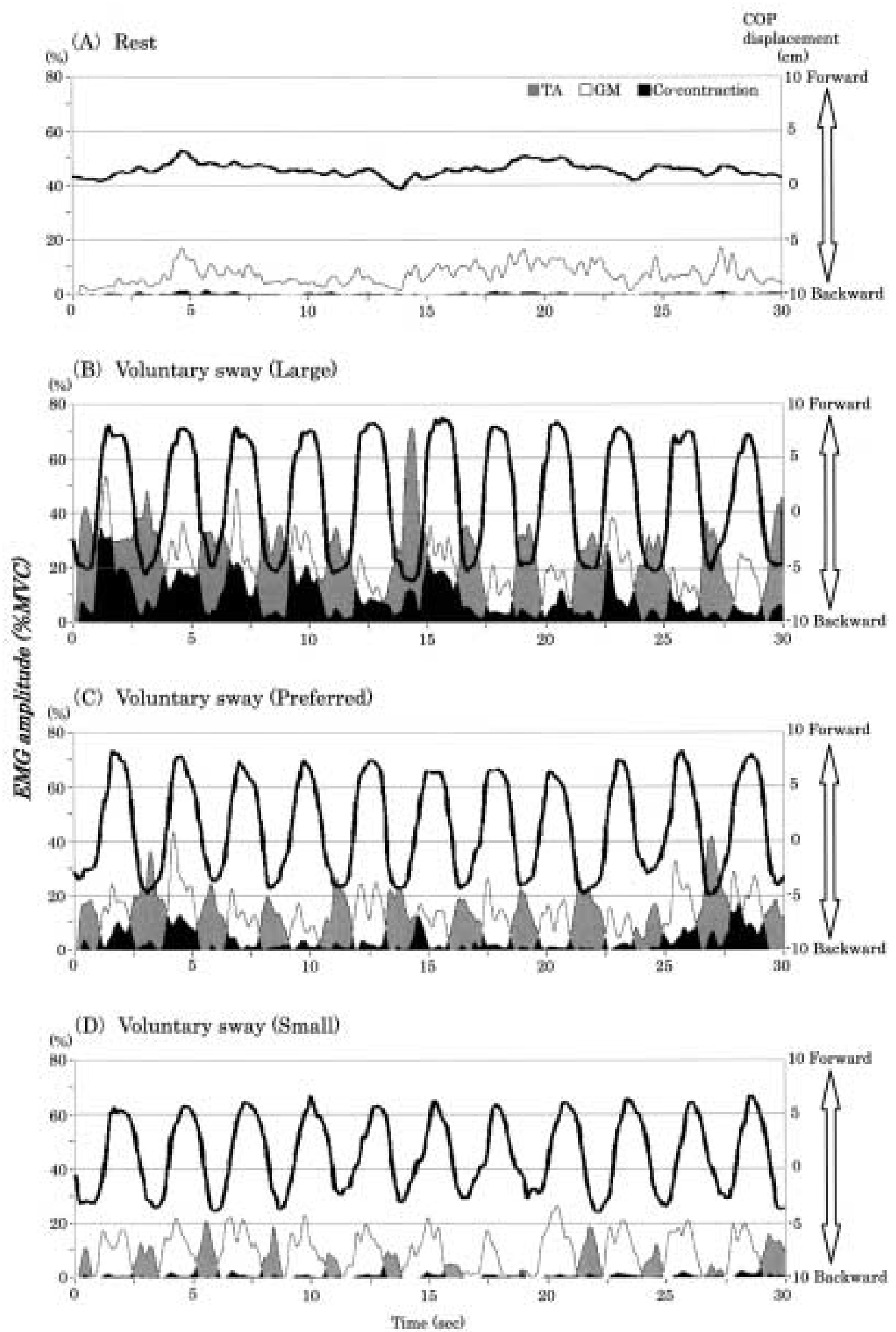

Figure 5. Examples of EMG and COP trajectory for an old participant during the upright stance as rest (A) and the voluntary sway task with the amplitude of Large (B), Preferred (C), and Small (D) at the middle speed of $0.375 \mathrm{~Hz}$. Gray, white, and black areas show EMG of the tibialis anterior, gastrocnemius, and $\mathrm{co}^{-}$contraction, respectively. 
Table 4-1. Balance tests of the old and young groups

\begin{tabular}{|c|c|c|c|c|c|c|}
\hline & \multirow{2}{*}{ unit } & \multicolumn{2}{|c|}{ Old $(n=17)$} & \multicolumn{2}{|c|}{ Young $(n=14)$} & \multirow{2}{*}{ P-value } \\
\hline & & mean & S.D. & mean & S.D. & \\
\hline $\mathrm{LNG}^{1)}-\mathrm{EO}^{3)}$ & $\mathrm{cm}$ & 45.3 & 12.3 & 33.4 & 8.9 & $<0.01$ \\
\hline $\mathrm{AREA}^{2)-\mathrm{EO}}$ & $\mathrm{cm}^{2}$ & 2.8 & 1.2 & 1.8 & 0.9 & $<0.05$ \\
\hline LNG-EC4) & $\mathrm{cm}$ & 66.1 & 14.1 & 48.3 & 18.3 & $<0.01$ \\
\hline AREA-EC & $\mathrm{cm}^{2}$ & 3.8 & 1.9 & 2.3 & 0.9 & $<0.01$ \\
\hline Functional reach & $\mathrm{cm}$ & 42.1 & 3.9 & 44.4 & 4.8 & n.s. \\
\hline $\mathrm{OLS}^{5 /-}$-EO & $\mathrm{sec}$ & 56.9 & 12.6 & 60.0 & 0.0 & n.s. \\
\hline OLS-EC & $\sec$ & 21.7 & 21.5 & 54.6 & 10.9 & $<0.001$ \\
\hline Speed of walking & $\mathrm{m} / \mathrm{sec}$ & 2.4 & 0.2 & 2.8 & 0.4 & $<0.001$ \\
\hline Step length of walking & $\mathrm{cm}$ & 83.3 & 5.4 & 86.5 & 6.9 & n.s. \\
\hline Cadence of walking & step/min & 170.0 & 15.1 & 193.3 & 20.8 & $<0.01$ \\
\hline $\mathrm{SOT}^{6)}$ & points & 73.0 & 7.4 & 78.0 & 5.4 & $<0.05$ \\
\hline C1 score & points & 93.4 & 1.5 & 94.1 & 1.6 & n.s. \\
\hline $\mathrm{C} 2$ score & points & 92.4 & 2.7 & 92.7 & 2.0 & n.s. \\
\hline C3 score & points & 84.3 & 7.2 & 88.3 & 3.1 & n.s \\
\hline C4 score & points & 77.9 & 7.7 & 80.9 & 8.1 & n.s. \\
\hline C5 score & points & 56.4 & 19.6 & 61.4 & 12.5 & n.s. \\
\hline C6 score & points & 53.4 & 13.5 & 66.1 & 12.4 & $<0.05$ \\
\hline $\mathrm{MCT}^{7}$ & $\mathrm{~ms}$ & 128.9 & 7.6 & 124.2 & 6.1 & n.s. \\
\hline Foot length $\% 8$ & $\%$ & 69.3 & 4.4 & 73.8 & 4.4 & $<0.01$ \\
\hline \multicolumn{7}{|c|}{ 1) LNG: Excursion length of body sway } \\
\hline \multicolumn{7}{|c|}{ 2) AREA: Area ellipse of body sway } \\
\hline \multicolumn{7}{|c|}{ 3) EO: Eyes open, 4) EC: Eyes closed } \\
\hline \multicolumn{7}{|c|}{ 5) OLS: One leg standing } \\
\hline \multicolumn{7}{|c|}{ 6) SOT: Total score in Sensory Organization Test } \\
\hline \multicolumn{7}{|c|}{ 7) MCT: Latency in Motor Control Test } \\
\hline \multirow{2}{*}{ 8) Foot length $\%=$} & \multicolumn{6}{|c|}{ Maximum displacement of center of foot pressure } \\
\hline & & & 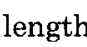 & & & \\
\hline
\end{tabular}

Table 4-2. Isokinetic peak torques for the old and young groups

\begin{tabular}{lcccccc}
\hline & \multicolumn{2}{c}{$\operatorname{Old}(\mathrm{n}=17)$} & \multicolumn{2}{c}{ Young $(\mathrm{n}=14)$} & \multirow{2}{*}{ P-value } \\
\cline { 2 - 5 } & mean & S.D. & mean & S.D. & \\
\hline Planter flexion $60^{\circ} / \mathrm{sec}$ & 0.65 & 0.18 & 0.87 & 0.20 & $<0.01$ \\
Planter flexion $180^{\circ} / \mathrm{sec}$ & 0.37 & 0.08 & 0.46 & 0.14 & $<0.05$ \\
Dorsiflexion $60^{\circ} / \mathrm{sec}$ & 0.27 & 0.09 & 0.31 & 0.13 & n.s. \\
Dorsiflexion $180^{\circ} / \mathrm{sec}$ & 0.18 & 0.04 & 0.21 & 0.08 & n.s. \\
\hline
\end{tabular}

unit: $\mathrm{Nm} / \mathrm{kg}$ 
Table 5. Multiple regression analysis for CCI

\begin{tabular}{lcccc}
\hline & Model I & Model II & Model III & \multirow{2}{*}{$\mathrm{r}$} \\
\cline { 2 - 4 } & $B$ & $B$ & $B$ & \\
\hline C2 score & $0.43^{* *}$ & $0.41^{* *}$ & $0.42^{* *}$ & $0.45^{*}$ \\
Functional reach & $-0.44^{* *}$ & $-0.37^{*}$ & $-0.31^{*}$ & $-0.46^{* *}$ \\
Dorsiflexion $180^{\circ} / \mathrm{sec}$ & & $-0.40^{* *}$ & $-0.35^{*}$ & $-0.50^{* *}$ \\
Age & & & 0.22 & $0.38^{*}$ \\
\hline $\mathrm{R}$ & $0.63^{* *}$ & $0.74^{* *}$ & $0.77^{* *}$ & \\
$\mathrm{R}^{2}$ & 0.39 & 0.55 & 0.59 & \\
Adjusted $\mathrm{R}^{2}$ & 0.35 & 0.49 & 0.53 & \\
$\Delta \mathrm{R}^{2}$ & & 0.14 & 0.04 & \\
\hline$*_{\mathrm{p}<0.05, * *}<0.01$ & & & &
\end{tabular}

本研究の課題を遂行するために決定的に重要であ る.なぜならば, 本研究で用いた課題は直立姿勢を 維持し，主に足関節まわりのトルクを用いて体重心 を前後に動摇させるからである. 中高齢者群では前 脛骨筋と腓腹筋の同時収縮を起こし, 足関節の stiffnessを増加させ，足関節の安定性を増加させた と示唆される ${ }^{19,20)}$.つまり, 前後重心移動課題に おいて若年者は主動筋を活動させて足関節の安定性 を保持する一方，中高齢者は同時収縮を用いること で足関節の安定性を高めていたと言える .

中高齢者の同時収縮か強まった第 2 の要因に, 加 齢による相反抑制の低下が挙げられる．関節運動を 生じさせる主動筋の筋活動が起こると，反対側にあ る拮抗筋の筋活動が抑制される相反抑制が生じる． 相反抑制の加齢による低下はKido et al. ${ }^{21)}$ と

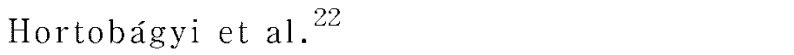

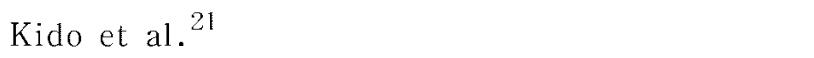
して総腓骨神経刺激によるヒラメ筋 H反射の抑制， 脛骨神経刺激による前脛骨筋H反射の抑制を観察し た . 本研究における課題中, 中高齢者は同時収縮に みられたような強い拮抗筋の筋活動を示した要因の 一つとして相反抑制の低下が示唆される.しかし ながら, Kido et al. ${ }^{21)}$ が用いた立位姿勢や歩行で はなく，本研究のような課題を用いることによる， 加齢によって低下する相反抑制を含めた神経機構の 解明は将来の課題である .

この他に，同時収縮に影響する要因に課題に対す る恐怖感が挙げられる.Llewellyn et al.は,トレッ ドミル歩行時に比べて平均台歩行時に同時収縮の増
加，H反射の減衰がみられたことを報告している ${ }^{23)}$. さらに, Okada et al.は, 高齢者において起立台の 移動による加速度外乱時の足関節筋の筋活動を観察 したところ, 転倒恐怖を持つ者は足関節筋の同時収 縮が強かったことを報告している ${ }^{24)}$.このように， 本研究の若年者に比べて中高齢者は転倒に対する恐 怖心を持っていたために同時収縮が強まった可能性 がある .

C. 同時収縮とバランス能力, 筋力の関連

本研究における足関節筋の同時収縮は, バランス 能力ならびに筋力と関連する可能性があるため, 重 回帰分析を用いて検証した . 谷の結果, バランステ ストだけを投入したモデルＩにおいて，EquiTest のC2 とファンクショナルリーチが抽出された . モ デル II で筋力を加えると, さらに足背屈ピークトル クが抽出された . 同時収縮の強い者は弱い足背屈力 を示したことから，同時収縮はバランス能力だけで なく，筋力とも関連のあることが示唆された . C2 は閉眼での静止立位時における前後方向への足圧中 心の移動距離であるから静的バランス能力を示す． また , ファンクショナルリーチは随意的な重心の移 動を伴うことから，動的バランス能力を示すと言え る.さらに, 同時収縮の強さと $\mathrm{C} 2$ 得点に正の相関 がみられ, ファンクショナルリーチと足背屈力乥れ ぞれに負の相関がみられた .

以上のように，同時収縮が強まることは静的バラ ンス能力の向上, 動的バランス能力の低下, 筋力の 低下を反映していると言える． 


$$
\text { V.結論 }
$$

本研究は足関節を軸に体を前後方向に傾ける前後 重心移動課題中にみられる同時収縮の加齢による影 響，ならびに同時収縮とバランス能力, 筋力との関 連を明らかにするために行った 中高齢者17名(64.1 \pm 2.9 歳) と若年者 14 名 (21.3 23.3 歳) を対象に， 前後重心移動課題中にみられる前脛骨筋と腓腹筋の 同時収縮を観察した .このために前後重心移動課題 における足圧中心の移動距離（振幅）と速度を 3 段 階ずつ組み合わせ , 合計 9 条件を用いた . 前後重心 移動課題中, 中高齢者は若年者と比較して同時収縮 が強かった．また，両群で課題中の振幅が大きくな ると同時収縮は強かった . しかしながら, 速度を増 しても同時収縮の強さに変化はみられなかった . 重 回帰分析の結果, 同時収縮は EquiTestのC2 (閉眼 立位時の動摇) と正に, ファンクショナルリーチと 足背屈力と負に相関した。

以上より, 本研究は, 同時収縮が前後重心移動課 題の速度ではなく振幅に依存し，加齢で増大するこ と, また, 同時収縮か清争的バランス能力と正に, 動 的バランス能力や筋力と負に関連することを明らか にした 。

\section{謝 辞}

本研究を遂行するにあたり，有益な助言を頂いた大阪 大学大学院医学系研究科の橋詰謙准教授に感謝の意を表 します．

\section{(受理日 平成21年11月11日)}

\section{参 考 文 献}

1）鈴木隆雄，転倒の疫学，日老医誌，(2003)，40,85-94.

2) 川上治，加藤 雄一郎，太田 壽成，高齢者における 転倒・骨折の疫学と予防 ,日老医誌, (2006), 43, 7-18.

3) 中村隆一, 齋藤宏, 長崎浩. 基礎運動学, 第6 版, 姿勢, 医歯薬出版, 東京, (2008)，347-355.

4) Manchester, D., Woollacott, M., Zederbauer-Hylton, N., Marin, O. Visual, vestibular and somatosensory contributions to balance control in the older adult. J Gerontol., (1989), 44, M118-M127.

5) Laughton, C.A., Slavin, M., Katdare, K., Nolan, L., Bean, J.F., Kerrigan, D.C., Phillips, E., Lipsitz, L.A., Collins, J.J. Aging, muscle activity, and balance control: physiologic changes associated with balance impairment. Gait Posture, (2003), 18, 101-108.

6) Benjuya, N., Melzer, I., Kaplanski, J. Aging-induced shifts from a reliance on sensory input to muscle cocontraction during balanced standing. J Gerontol., (2004), 59A, M166-M171.

7) Berg, W.P., Alessio, H.M., Mills, E.M., Tong, C. Circumstances and consequences of falls in independent community-dwelling older adults. Age Aging., (1997), 26, 261-268.

8) Load, S.R., Ward, J.A., Williams, P., Anstey, K. Physiological factors associated with falls in older community-dwelling women. J Am Geriatr Soc., (1994), 42, 1110-1117.

9) Davis, J.W., Ross, P.D., Nevitt, M.C., Wasnich, R.D. Risk factors for falls and for serious injuries on falling among older Japanese women in Hawaii. J Am Geriatr Soc., (1999), 47, 792-798.

10) 時田 喬. 重心動摇検査 兴の実際と解釈, アニマ, 東京，(2002)，1-16。

11) Duncan, P.W., Weiner, D.K., Chandler, J., Studenski, S. Functional Reach: A new clinical measure of balance. J Gerontol., (1990), 45, M192-M197.

12) 古名丈人, 長崎浩, 伊藤 元, 橋詰謙, 衣笠隆, 丸山 仁司，都市および農村地域における高龄者の運 動能力，体力科学，(1994)，44，347-356.

13) Jacobson, G.P., Newman, C.W., Kartush, J.M, Handbook of balance function testing, 1st Ed., PART IV, Posturographic Testing, Singular, London, (1997), 261-307.

14) Falconer, K., Winter, D.A. Quantitative assessment of co-contraction at the ankle joint in walking. Electromyogr Clin Neurophysiol., (1985), 25, 135-149.

15) Kellis, E., Arabatzi, F., Papadopoulos, C. Muscle co-activation around the knee in drop jumping using the co-contraction index. J Electromyogr Kinesiol., (2003), 13, 229-238.

16) 衣笠隆, 長崎浩, 伊藤元, 橋詰謙, 古名丈人, 丸山 仁司，男性(18－83歳)を対象にした運動能力の 加齢変化の研究, 体力科学, (1994), 43, 343-351.

17) Horak, F.B., Diener, H.C., Nashner, L.M. Influence of central set on human postural responses. J Neurophysiol., (1989), 62, 841-853.

18) Maki, B.E., Ostrovski, G. Scaling of postural responses to transient and continuous perturbations. Gait Posture, (1993), 1, 93-104.

19) Nielsen, J., Sinkjaer, T., Kagamihara, Y. Segmental reflexes and ankle joint stiffness during $\mathrm{co}^{-}$contraction of antagonistic ankle muscles in man. Exp Brain Res., (1994), 102, 350-358.

20) Granata, K.P., Wilson, S.E., Massimini, A.K., Gabriel, R. Active stiffness of ankle in response to inertial and elastic loads. J Electromyogr Kinesiol., (2004), 14, 599-609.

21) Kido, A., Tanaka, N., Stein, R.B. Spinal excitation and inhibition decrease as humans age. Can J Physiol Pharmacol., (2004), 82, 238-248.

22) Hortobágyi, T., del Olmo, M.F., Rothwell, J.C. Age reduces cortical reciprocal inhibition in humans. Exp 
Brain Res., (2006), 171, 322-329.

23) Llewellyn, M., Yang, J.F., Prochazka, A. Human $\mathrm{H}$-reflexes are smaller in difficult beam walking than in normal treadmill walking. Exp Brain Res., (1990), $83,22-28$.
24) Okada, S., Hirakawa, K., Takada, Y., Kinoshita, H. Relationship between fear of falling and balancing ability during abrupt deceleration in aged women having simi lar habitual physical activities. Eur J Appl Physiol., (2001), 85, 501-506. 